\title{
Ratnakīrti and Dharmottara on the Object of Activity
}

\author{
Patrick Mc Allister
}

Published online: 13 November 2013

(C) The Author(s) 2013. This article is published with open access at Springerlink.com

\begin{abstract}
This article examines two Buddhist explanations of how a conceptual cognition, whose object is a universal, can give rise to activity that leads to a particular. In both theories, that of Dharmottara and that of Ratnakīti, this activity is due to a kind of error. A detailed investigation of how this error happens shows that there were big differences in the two underlying epistemological models.
\end{abstract}

Keywords Buddhist epistemology - Conceptual cognition · Determination · Dharmottara $\cdot$ Ratnakīrti

This article ${ }^{1}$ tries to answer the following question: what exactly is it that Ratnakīti overtly criticizes about Dharmottara's theory of conceptual cognition (i.e., his apoha theory) $?^{2}$

This question touches upon a topic which was extensively discussed both within various sub-groups of Indian Buddhism, and between Indian Buddhists and their non-Buddhist opponents, amongst whom the Naiyāyikas and Mīmāṃsakas stand out

\footnotetext{
${ }^{1}$ The research for this article, as well as my attendance at the XVIth Congress of the IABS in Taiwan where I read my first draft of the material, was funded by the Austrian Science Fund (FWF): NFN S9805, Subproject "Philosophy" of the National Research Network "The Cultural History of the Western Himalaya from the 8th Century (S98)." I would like to thank Markus Viehbeck and Masamichi Sakai for their valuable comments on this article.

${ }^{2}$ What Ratnakīrti criticizes here is, of course, also criticized by his teacher Jñānaśrīmitra. But in this article I am more interested in the way that Ratnakirti presents the matter. Covertly, Ratnakīrti criticizes a few things about Dharmottara's apoha theory. Akamatsu (1986) is the most detailed treatment of differences between Dharmottara and Ratnakirti. McCrea and Patil (2006) cover the relation between Dharmakīrti, Dharmottara and Jñānaśrīmitra.
}

P. Mc Allister ( $\square)$

Vienna, Austria

e-mail: pma@rdorte.org 
in Ratnakīrti's writings. ${ }^{3}$ At its broadest, this topic concerns the question of whether cognition has a form or not; ${ }^{4}$ and, if it has one, what exactly that form is, and what its role in cognition is. The focus of this article, however, is to analyse what the 11th century ${ }^{5}$ Buddhist monk and scholar Ratnakirti had to say about this question in the specific context of a criticism of an earlier Buddhist scholar, Dharmottara (ca. 740$800 \mathrm{CE}$ ), who wrote extensively and originally about the same problem. The line of inquiry is further narrowed down by a confinement to only two of Ratnakīrti's texts, the Apohasiddhi (AS) and the Citrādvaitaprakāsavāda (CAPV).

The reason for focusing on these two texts is simple. First, it is in the AS that Ratnakīrti criticizes Dharmottara. This criticism is related to a discussion about the function of a form in cognition, and especially in conceptual cognition. Since this function is often appealed to in ways that are not easy to make good sense of, the preliminary question that must be answered is this: what is the role of a form ( $\bar{k} k \bar{a} r a)$ in determination (adhyavasāya) for Ratnakīti? To this end, then, the CAPV was selected because this is the text in which Ratnakirti discusses the role of cognition's form in the greatest detail, and it thus seemed most likely that what is difficult to understand in the AS is explained, or at least becomes clearer, in the CAPV. For a definitive assessment of Ratnakīrti's position, however, one will have to take into account also his other texts, a project that lies outside the scope of the present paper.

\section{Ratnakīrti’s Criticism of Dharmottara's Apoha Theory}

Ratnakīrti's criticism of an aspect of Dharmottara's apoha theory is found in the following passage: ${ }^{6}$

\footnotetext{
${ }^{3}$ Cf. Thakur (1975a, 16 ff.). In the Citrādvaitaprakāśavāda (CAPV), Ratnakīrti quotes Trilocana and Vācaspatimiśra by name (CAPV 135). From Vācaspati the Nyāyakanikā is quoted. What is surprising is that Ratnakirti apparently accepts the criticism expressed in those two quotes, of course only to modify the position accordingly in the next step.

${ }^{4}$ Katsura (1986, p. 178, n. 5) attributes nirākāravāda, the teaching that cognition is without form, to Dharmottara. Jñānaśrīmitra and Ratnakīrti are clearly adherents of the teaching that cognition does have a form (sākäravāda, cf. Kajiyama 1998, p. 155). These attributions are to be understood as pertaining to the cognition of an awakened being. In the CAPV, however, Ratnakīti definitely discusses the various positions as far as they concern a non-omniscient mind: tatrāsarvajñe 'numātari sakalavipaksapratibhāsābhāvān na grāhyataya aipakșo vișayo vaktavyah, ... (With regard to this [inference], in the case of a non-omniscient inferrer, the counter-instance is not to be called an object due to being grasped because there is no appearance of the whole counter-instance; ...)

The inference under discussion is the one that establishes that what appears to cognition is a unitary, variegated form (cf. footnote 15). The problem at this point (and in fact, for a big part: CAPV 130.33141.8 according to my understanding) is how one can know that the reason-that something appears to cognition-does not qualify a counter-instance (vipakșa)—something that is not one. For, a counterinstance either appears to cognition (in which case it is obviously qualified by the reason) or does not (in which case it is difficult to say much about it).

${ }^{5}$ All the dates for historical figures' lives in this article are taken from Steinkellner and Much (1995), unless noted otherwise.

${ }^{6}$ Patil (2011) contains a full translation of the AS, as does Mc Allister (2011).
} 
Passage 1: Criticism of Dharmottara $\mathrm{So}^{7}$ in this way an affirmation[, as well as a negation,] in reality establishes neither a form [of awareness] nor an external [object]. For, [affirmation and negation] conventionally [establish an object] only externally. But even conventionally [there is] no [such establishment] of a form. ${ }^{8}$ Through this [verse] what Dharmottara says uncommonly, against scripture, and illogically, namely that [there is] affirmation and negation of the externality of that which is superimposed, is also rejected.

Ratnakīrti's further explanations about this point are concerned to show that determination as he understands it is possible, and does not lead to the problems that a superimposition due to similarity would. ${ }^{9}$ Ratnakīrti does not go into much detail concerning what those problems would be. The main point seems to be that similarity between an appearance internal to the mind and the external object is not sufficient for successful activity; rather, determination, which directs this activity, works just due to a connection to a specific internal object (ākāraviśeșayogāt, AS 66.2), and so the external thing plays no important role in this explanation of activity. ${ }^{10}$

So all we have to go on, so far, is that Ratnakīrti criticizes Dharmottara for assuming that affirmation and negation are directed at "the externality of that which is superimposed." In order to proceed, we therefore need to find out, first, what Ratnakīrti takes the object of affirmation and negation to be, and, second, what the difference is to Dharmottara's position.

\section{Determination and Forms in the AS}

In the following two passages of the AS a relation between determination and form can be seen quite easily. In both of these passages, Ratnakīti is explaining his

\footnotetext{
${ }^{7}$ AS 65.20-24: tad evam

nākārasya na bāhyasya tattvato vidhisādhanam | bahir eva hi saṃvrtyā samvvrtyāpi tu nākṛteh || etena yad dharmottarah - āropitasya bāhyatvasya vidhiniședhāv ity alaukikam anāgamam atärkikīyam kathayati, tad apy apahastitam. As noted by Frauwallner (1937, p. 266, n. 1), Dharmottara makes this point in his Apohaprakarana (DhAP 244.3-4): sgrub pa dan dgag pa dag ni sgro btags gañ źig phyi rol ñid du nies par byas pa de dan 'brel pa yin te. See Passage 6 for a translation of the passage. Frauwallner (1937, p. 266) translates this sentence as: "Dagegen wird eine Bejahung oder Verneinung mit dem Übertragenen verbunden, das als außen bestimmt wird." The Sanskrit quoted by Ratnakīrti does not match up to the Tibetan in at least one important respect: an equivalent for ies par byas pa is missing.

${ }^{8}$ The translation of this verse by McCrea and Patil (2006, p. 338) is as follows: "There is no way of really affirming either the mental image or the external object. Conventionally [there is affirmation] only of externals, whereas even conventionally there is no [affirmation] of the mental image."

9 Jñānaśrimitra argues for each of the three claims (against scripture, common sense, and logical reason), and a fine translation can be found in McCrea and Patil (2010, 92 ff.). The gist of Jñānaśrīmitra's argument is that without basing oneself on the two truths, conventional and absolute, an object of everyday activity (classically a cow) can not be talked about. If one tries to explain it without recourse to these two truths, one goes against common understanding, according to which one acts simply towards a real object. One similarly goes against tradition, because it maintains that in reality nothing real at all can be named by words. And one also goes against reason, because the position is untenable.

${ }^{10}$ Much of what is here only hinted at by Ratnakīrti is repeated and discussed in more detail in CAPV $138.12 \mathrm{ff}$.
} 
definition of the word-referent: a positive element (vidhi) qualified by the exclusion from others (anyāpohaviśișto vidhiḥ śabdānām arthah (AS 59.5)) The aim of this formulation is to balance two elements that many of Ratnakīrti's predecessors take as instrumental in using concepts: a negative one, the exclusion of what is not meant by a word (anyāpoha), and a positive one, which, according to Ratnakīrti, can be seen both as a representation appearing to awareness and as an object that is imagined as external and temporally extended. In Ratnakīrti's theory, the negative element should be taken as a property of the positive one. ${ }^{11}$

Passage 2: vidhi (a) And ${ }^{12}$ by the word "positive element" an external object that is distinguished from that of another nature is meant according to determination, and according to appearance a form of awareness [is meant]. Amongst these, the external object is defined as that to be expressed by a word because of determination alone, not because of a particular's appearance, since there is no appearance of a manifest particular that is limited as to space, time and condition, as there is in the case of perception.

Passage 3: vidhi (b) So ${ }^{13}$ in this way only a positive element is the referent of a word. And this [positive element] is intended to be called the external object and the form of awareness. Amongst these, [there is] no affirmation [or] negation of the form of awareness in reality or in a conventional sense, because of the fact that [it] is understood through a perception [of the type] self-awareness, and because [the form of awareness] is not determined. In reality, too, there is no negation or affirmation of the external either, because of its non-appearance in verbal apprehension. Precisely for this [reason] all properties [of an object] are inexpressible in reality, because there is no determination [or] appearance [of them]. Therefore there is conventional affirmation and negation of an external [object] only, because otherwise there is the [unwanted] consequence that everyday interaction is ruined.

The first of these passages (Passage 2) is concerned with the interpretation of the positive part in the definition, the vidhi. It is said to have two sides, depending on how it is present to awareness: if determined, it is an external object differentiated from certain other objects; if manifest, or directly present to awareness, it is a form of awareness.

Building on this, Ratnakīrti says in the Passage 3 how this vidhi is the object of activity (either positive or negative), distinguishing two ways of looking at the situation: in reality, on the one hand, no aspect of the vidhi, neither the determined and external nor the manifest and internal aspect, is the object that people usually act towards. In a conventional sense, on the other hand, the external aspect of the

\footnotetext{
${ }^{11}$ For the reason why this issue is important, see Akamatsu (1986) and Kataoka (2009, $\left.484 \mathrm{ff}\right)$.

12 AS 60.20-23: vidhiśabdena ca yathādhyavasāyam atadrūpaparāvrtto bāhyo 'rtho 'bhimatah, yathāpratibhāsam buddhyākāraś ca. tatra bāhyo 'rtho 'dhyavasāyād eva śabdavācyo vyavasthāpyate, na svalakșaṇaparisphūrtyā, pratyakșavad deśakālāvasthāniyatapravyaktasvalakșaṇāsphuraṇāt.

13 AS 65.15-20: tad evam vidhir eva śabdārthah. sa ca bāhyo 'rtho buddhyākāraś ca vivakșitah. tatra na buddhyākārasya tattvatah samvrrtyā vā vidhiniṣedhau, svasamvedanapratyakșagamyatvād anadhyavasāyāc ca. nāpi tattvato bāhyasyāpi vidhiniședhau, tasya śābde pratyaye 'pratibhāsanāt. ata eva sarvadharmānā̄m tattvato 'nabhilāpyatvam, pratibhāsādhyavasāyābhāvāt. tasmād bāhyasyaiva sāṃvrtau vidhiniședhau, anyathā samvvavahārahāniprasaìgāt.
} 
vidhi is indeed what we act towards. The internal aspect is not an object even in this conventional sense.

Many questions might be raised as to what these two statements about the vidhi are suggesting: is it one vidhi, seen in two different ways, or two vidhis? Are these two things or aspects somehow related, so that one could not exist without the other, or do they occur independently of each other? Is there some kind of causal relation between them?

For the purpose of our investigation, I would like to avoid most of the difficulties one gets into by asking these questions, and just focus on one subset of the problem: how is the internal aspect of the vidhi, the form appearing to awareness, linked to activity that has an external object as its aim? In other words, how is the result of determination linked to the form appearing to cognition?

In order to answer this question, one has to know what determination is. Fortunately, the last few years have seen plenty of progress on the concept of determination, or adhyavasāya. The most useful publications for our purposes are McCrea and Patil (2006), which focuses on Jñānaśrīmitra's view on determination and its philosophical history, and Patil (2009, pp. 250-288), which analyzes Ratnakīrti's epistemology very closely. ${ }^{14}$

\section{Determination in Ratnakīrti's AS}

The two main functions of determination, or adhyavasāya, in Ratnakīrti's theory of conceptual cognition are the externalisation and the generalization of a form (ākāra), something that is "in" cognition. ${ }^{15}$

The easier one to understand is the externalisation component: a person who perceives, by means of self-awareness, a form that appears in cognition determines this form as external, or as being an external object. In the AS, Ratnakīrti does not give any detailed explanations as to how this externalisation works. But there is a passage in the CAPV in which he does: ${ }^{16}$

\footnotetext{
${ }^{14}$ Both of these publications are concerned also with the more general questions just mentioned. In addition, I have tried to look at adhyavasāya's role in the AS myself (Mc Allister, forthcoming). In the following, I build also on that article's main points.

15 In the guiding inference of the CAPV, Ratnakīrti gives a detailed list of what the term ākāra can refer to:

CAPV 129.22-24: yat prakāśate tad ekam. yathā citrākāracakramadhyavartī nīlākārah. prakāśate cedam gauragāndhāramadhurasurabhisukumārasātetarādivicitrākārakadambakam iti svabhāvahetuh. (What appears, that is one. Like the form of blue occurring amidst a circle of various forms. And this collection of various forms, [such as] white, sounding [like the third note] "ga," sweet, fragrant, soft, pleasurable and the opposite [of it], etc., appears. [This is a proof using] the nature [of the pakșa as] a reason.)

Even though I am not completely confident about my translation (especially whether the understanding of gāndhāra is correct), the main points of this passage are clear: in one appearance to cognition, multiple "forms" are present to awareness. A "form," ākāra, thus corresponds to or represents properties of objects. But it should not be understood as being restricted to the shape of a thing, since a thing can appear to awareness in the form of its smell, its sound, etc.

${ }^{16}$ In fact, this explanation is given in defense of Prajñākaragupta's position (cf. CAPV 137.6-9).
} 
Passage 4: adhyavasāya according to the CAPV For ${ }^{17}$ it is so: based on the mere knowledge of a particular appearance of [cognition] itself, which is attained by the power of an immediately [preceding] cause, determination incites activity toward something else, even though [that is] not grasped. ...

For it is so: in virtue of beginningless variegated impressions, a conceptual cognition, arising, in dependence on a particular cause that awakens [these impressions], with a certain form, brings forth a connection [to] a memory of causal efficacy, desire [for such an efficacy], etc., which is conducive towards activity directed towards an external object. Because of this, there are, for someone aiming to bring about an aim of a human being, regulations for positive and negative activity [such that these regulations] correspond to the external things, because a similar relation of cause and effect, which the moments [making up] the continuous flow of an unawakened being have, is fixed. ${ }^{18}$

The externalisation that determination performs is therefore best understood as a directing at something that is actually not represented in this directing awareness in any way. It would seem, then, that this externalisation does not really show something internal to cognition as something external, but rather that it incites activity towards an unseen external thing based on something appearing to cognition. The point stressed here is that the link between the internal and external component is not, or at least not primarily, one of phenomenal similarity (what appears does not look like something out there), but a kind of causal similarity, such that what appears is the effect of something (usually a perception) awakening impressions gathered throughout a mental continuum's career, and is in turn a cause for doing something about something "out there."

A proper interpretation of the second function of determination, generalization, presupposes an understanding of the apoha theory. The difficulties of arriving at an adequate understanding of this theory are considerable, ${ }^{19}$ and even if successful this understanding would not contribute much to answering the question that is of interest to us. ${ }^{20}$ For our current purpose, it may then be enough to say that the

\footnotetext{
17 CAPV 137.9-16: tathā hi samanantarapratyayabalāyātasvapratibhāsaviśeșavedanamātrād agrhīte 'pi paratra pravrttyākșepo 'dhyavasāyah. ...

tathā hi vicitrānādivāsanāvaśāt prabodhakapratyayaviśeșāpekșayā vikalpaḥ kenacid ākārenopajāyamāna eva bahirmukhapravrttyanukūlam arthakriyāsmaraṇābhilāṣādiprabandham ādhatte. tatah puruṣārthakriyārthino bahirarthānurūpāṇi pravrttinivṛttyavadhāraṇāni bhavanti, pṛthagjanasantānajñānakșaṇānām tādríso hetuphalabhāvasya niyatatvāt.

18 I am not quite sure how to understand that this relation is similar. It could mean that the cause-effect relation governing the moments of a mental continuum can not be completely different from that governing the object's continuum. To explain, if a moment in the continuum constituting a particular cow causes a perceptual cognition, the causal chains arising from that moment - that of the cow itself and that resulting in my climbing back over the fence subsequent to my cognition "Oh, a cow!"- - are similar in some regard. One point in common would be that they are bound to the same cause.

19 Also, there are other, better attempts than can be given here: for Ratnakīti in particular, cf. Patil (2003; 2009, Chap. V), and my own attempt in Mc Allister (2011, Chap. 5).

20 Such an inquiry would, however, explain how the $\bar{a} k \bar{a} r a$ can be qualified by other-exclusion (i.e., the anyāpohaviśișta in the definition referred to above). I have tried to specify this relation in Mc Allister (2011, Sect. 5.3).
} 
central problem Ratnakīrti, as many Buddhist epistemologists before him, purports to solve with this theory is how it is possible that two different particulars are judged to be the same. So let us imagine the apoha theory is successful in this regard, and is indeed a viable way of making sameness possible, or of classifying things, such that in the following we can simply speak of things being judged as the same instead of things being judged as being differentiated from the same sort of other things.

In this case, one aspect of the apoha theory remains which is of interest to us: ${ }^{21}$ namely, the way in which a form or $\bar{a} k \bar{a} r a$ can be the basis for a conceptual cognition of sameness.

Ratnakīrti's answer is well in line with the account given by Dharmakīrti: the $\bar{a} k \bar{a} r a$ is involved in an error inherent in conceptual cognition. ${ }^{22} \mathrm{He}$ explains this in detail in the following passage:

Passage 5: Erroneous appearance Neither $^{23}$ does a universal appear in a verbal cognition. Because of a word such as "cow" etc. in [the sentence] "Cows are grazing on the other side of the river," dewlap, horn, tail etc. appear, [which are] accompanied by the forms of phonemes, [and which are] mostly [just] lumped together ${ }^{24}$ because differences between [things] belonging to the same genus are disregarded. But exactly this is not a universal. For [the universal] "cowness" is proclaimed to be devoid of colour, shape, and the forms of phonemes. But precisely this mere [heap of] dewlap, horn etc., which is identified with the particular though completely different in every individual [cow], is called a universal. This [is] only an error because such an external [object] is not obtained, like the appearance of hair [to someone suffering from an eye disease is only an error]. ${ }^{25}$ Therefore, [a universal] may either be this

\footnotetext{
${ }^{21}$ Perhaps one should be careful about calling this an aspect of the apoha theory. If the apoha theory is taken to involve psychological or epistemological explanations about how apoha is understood, then this role that the ākâras play should certainly be called a part of it. But seeing it like this might lead one to think that the apoha theory is also what explains why the ākāras play the role they do. I think this is not what the apoha theory was intended to do, but is rather something that is part of the broader theory about how cognition (of unawakened beings) works. And it is this theory, or conceptual framework, which explains why forms play different roles in conceptual cognition. The apoha theory would then be adopted to work within this overall framework.

22 Cf. PVin 2 k. 1, and the interpretation (based on the Tibetan text and Sanskrit fragments) in Steinkellner (1979, 26 f.).

23 AS 63.10-19: nāpi sāmānyam śābdapratyayapratibhāsi. saritaḥ pāre gāvaś carantīti gavādiśabdāt sāsnāśrnigalāngūlādayo 'kșarākāraparikaritāḥ sajātīyabhedāparāmarśanāt sampiṇ̣̂itaprāyāh pratibhāsante. na ca tad eva sāmānyam. varṇākrtyakṣarākāraśūnyạ̣ gotvam hi kathyate I

tad eva ca sāsnāśringādimātram akhilavyaktāv atyantavilakṣanam api svalakșanenaikīkriyamānam sāmānyam ity ucyate. tādṛ́sasya bāhyasyāprāpter bhrāntir evāsau, keśapratibhāsavat. tasmād vāsanāvaśād buddher eva tadātmanā vivarto 'yam astu, asad eva vā tadrūpam khyātu, vyaktaya eva vā sajātīyabhedatiraskāreṇānyathā bhāsantām anubhavavyavadhānāt, smṛtipramoṣo vābhidhīyatām. sarvathā nirvișayah khalv ayam sāmānyapratyayah. kva sāmānyavārtā. The "neither" introduces the second alternative of how a real universal might become known. The first was that it could be perceived.

24 This translation for sampindita is borrowed from Patil (2011, p. 12).

25 Someone suffering from timira is said to see nets of hair which aren't really there. According to Chu (2004, p. 131, fn. 67), Anne MacDonald has identified timira as muscae volitantes (floaters).
} 
unfolding only of the mind itself as having the nature of this [universal] in virtue of remaining impressions; or [it may be] that having its[, i.e., the universal's,] form, which is simply inexistent, appears; or the individuals themselves might appear in some other way without regard to the differences of [things] belonging to the same genus because [differences amongst things] are hidden from experience; or a deprivation of memory may be considered [as the reason]. In all ways, this cognition of a universal is truly without an object. [So] where [is there] news of a universal?

In the first part of this passage, Ratnakīti explains what appears in a verbal cognition: in the case of the word "cow" this is apparently a dewlap, horn, tail, etc. Note that the word "cow" in the example sentence is plural, so "dewlap, horn, tail, etc." should be taken to jointly characterize several cows.

First, the form appearing to conceptual awareness has what one might want to call an inner structure, such that what appears on understanding the word "cow" is not a single, unitary appearance (like, I imagine, blue), but has internal distinctions into elements corresponding to the parts of cows. ${ }^{26}$

A second characteristic of this form is that its elements are "lumped together" because the differences between the individual cows grazing on the other side of the river are not taken into account. That means that what appears on understanding the word "cow" is a dewlap, a pair of horns, a tail and so on, each of which one thinks are common to all the cows one is told are grazing on the other side of the river. One has lumped all these facets together because the differences found between all cows, e.g., that each has its own, specific dewlap, are not paid close attention to.

After stating that it is an error to take this appearance of a common dewlap, horn, tail etc. to be the appearance of a universal, Ratnakīrti mentions four possibilities for how this appearance can come about:

1. It is an unfolding of mind itself.

2. Something completely inexistent having the form of a universal appears.

3. The real things appear other than they are.

4. There is an unnoticed interference of memory with the appearance.

So it is only on the basis of an error that the form appearing in conceptual cognition can give rise to the idea of the sameness among things. But, like a net of hair appearing to someone suffering from timira, these forms do not allow a person to reach an external thing that corresponds to them. They are not representations of anything real.

These four possibilities are typically listed within the framework of so called khyāti theories, theories of (false) appearance. ${ }^{27}$

From Passage 4 we know that Ratnakīrti endorses the first possibility, according to which the appearance of classes is the unfolding of mind itself: it is in virtue of

\footnotetext{
26 Again, this correspondence is not primarily one of phenomenal similarity. In this case, one would of course expect phenomenal similarity only to the external cows, not to the word "cow." But not even the cows on the other side of the river are similar in this sense. They are similar only insofar as, if one were told to fetch a cow, one could cross the river and attempt to fetch a cow. What appears is a "mere thing" (vastumātra). See the discussion of the vastumatra by Patil (2009, $234 \mathrm{ff}$.), who translates the term as "thing-in-general". See also Ratnakīrti's argument against imposition due to similarity, below in Passage 7.

27 The most detailed treatment of these theories is found in Schmithausen (1965).
} 
variegated and beginningless impressions (vicitrānādivāsanāvaśāt) that a conceptual cognition is prepared to cause activity directed at an external thing. This means that Ratnakīrti has to be understood as maintaining an àtmakhyāti position, which says that it is cognition itself that appears. ${ }^{28}$

Let us sum up what we have so far been able to understand about Ratnakīrti's view on form, determination, and activity:

1. Activity is directed at something determined as external.

2. This determination is based on a form appearing to awareness.

3. What appears to awareness in order to be determined by it is conditioned by beginningless impressions.

4. What appears is not a representation of something external.

5. Ratnakīrti endorsed a kind of ātmakhyāti position.

\section{Dharmottara on Activity}

What now is Dharmottara's theory about how activity comes about? ${ }^{29}$

Steinkellner (1976, p. 124), having constituted the introductory verse of the Apohaprakaraṇa (DhAP) according to Cakradhara's Nyāyamañjarīgranthibhaniga, which preserves a Sanskrit version, ${ }^{30}$ renders the verse like this:

\footnotetext{
28 This is corroborated also by Schmithausen (1965, p. 234, n. 162), who says that Jñānaśrī maintains a form of ātmakhyāti in his Sākārasiddhiśāstra (SāSiŚā).

29 I will be focusing in the following on the DhAP, because it is there that the opinion of Dharmottara's, which is criticised by Ratnakīti, is stated. For a discussion of determination as presented in an important passage of Dharmottara's NBT, see McCrea and Patil (2006, 325 ff.).

30 The verse runs as follows, according to the edition by Steinkellner (1976):

buddhyā kalpikayā viviktam aparair yad rūpam ullikhyate buddhir no na bahir yad eva ca vadan nistattvam āropitam |

yas tattvaṃ jagato jagāda vijayī niḥśeșadoṣadvișām vaktāraṃ tam iha praṇamya śirasā 'pohaḥ sa vistāryate ॥
}

NMGBh 132.24 introduces the quote as follows: jĩ̄anārthābhyām anya eveti dharmottarah, tathā cāhāsau - ... (That [exclusion, the object of words, is] completely different from both cognition and object, is what Dharmottara [says]. And accordingly he says: ....) As Steinkellner (1976, p. 123, n. 2) notes, the first pāda, though with a corrupted ending ("völlig korrumpiert", Steinkellner 1976, p. 123, n. 2), is also quoted by Aniruddha. It is interesting to see what is said about the verse in VP 41.21-26:

buddhyā kalpikayā viviktam aparair yad rūpam ullikhyate buddhir no na bahir tad eva ca padam nihsattvam ābhāsate I

ity asya granthasyāyam arthah. kalpikayā buddhyāvikalpikayā buddhyā vāparair vikalpāntaraih viviktạ yad rūpam ullikhyate, tad buddhir api na bhavati, bāhyo 'py artho na bhavati. kutah ? yato 'paraih svalakșanajñānatadgrāhyāntarair viviktam prthakkrtam ābhāsate teșām ananuvrttatvāt, etasya cānuvrttatvena pratibhāsanād ity arthah. (This is the point of that text[, Dharmottara's Apohaprakarana]: That very form, which is depicted by conceptual awareness as separated from others, is neither awareness nor an external thing, and appears as a thing without real existence. The form, which, separated from others[, that is,] other conceptual cognitions, is depicted by a conceptual awareness or a non-conceptual awareness, is not awareness nor is it an external thing. Why? Since it appears separated[, that is,] disjoined, from others[, that is,] from the others that are the particular, the cognition itself, [and] that 
Having bowed my head to the teacher free from all errors, who has explained that form which is distinguished from others by conceptual cognition, and who has victoriously described to the world (its) nature by clarifying that it is neither cognition nor external, that it is unreal and superimposed, I here elaborate upon exclusion. ${ }^{31}$

The central claim expressed here is that the form (rüpa) which is differentiated by conceptual cognition is neither awareness nor an external thing, and that it is unreal and superimposed. ${ }^{32}$

Let us take a closer look at the statement for which Ratnakīti criticizes Dharmottara, as it appears in DhAP 244.1-9:

Passage 6: Dharmottara on the object of activity For $^{33}$ an external [object], awareness, a form, and a superimposed [thing] there is no negating or affirming conceptual cognition. Affirming and negating are connected with a superimposed [thing] that is ascertained as being external. For example, [when one mistakes a rope for a snake,] there is no cognition affirming and negating a snake for a material entity, the rope, since [that rope] does not appear [to that cognition]. [Such a cognition] does also not exist for the awareness "snake," the grasped form, and the snake that is superimposed, because they do not go astray with regard to what exists as their own proper nature. However, a superimposed snake which is ascertained as an external snake is ascertained as established or negated. $^{34}$

Footnote 30 continued

grasped by this [cognition], because these are not acted upon [by a person], and because this [form] appears as what is being acted upon. This is the intent [of that statement].)

31 This is my translation into English. The original German is:

Nachdem ich den von allen Fehlern freien Lehrer mit dem Haupte verehrt habe, der jene Form erklärt, die durch die vorstellende Erkenntnis von anderen unterschieden wurde, und siegreich der Welt (ihre) wahre Natur beschrieben hat, indem er erläutert, daß sie weder Erkenntnis noch außen, daß sie unwirklich und übertragen ist, verbreite ich mich hier über diese Sonderung. (Steinkellner 1976, p. 124)

A slightly diverging translation by Hisataka Ishida is quoted by Kataoka (2009, p. 486, fn. 17). Note that Steinkellner understands the phrase buddhyā kalpikayā viviktam aparair yad rūpam ullikhyate as "jene Form erklärt, die durch die vorstellende Erkenntnis von anderen unterschieden wurde". Another translation which seems possible to me is "the form which is depicted by conceptual cognition as distinguished from others." I will be presupposing this interpretation in the following.

32 Bhațta Jayanta understands this position as a major difference between Dharmakīti's and Dharmottara's apoha theories. Cf. Hattori (2006) and the conclusions drawn by Kataoka (2009, 487 ff.), who traces the roots of Dharmottara's opinion back to Arcața.

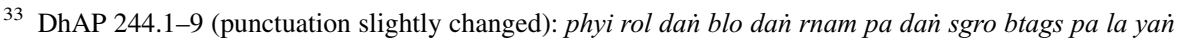

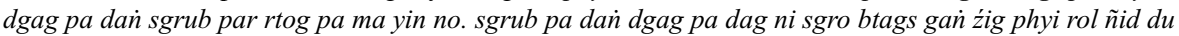
$\dot{n}$ es par byas pa de dan் 'brel pa yin te, dper na sbrul sgrub pa dan dgag pa'i śes pa thag pa'i rdzas la ni

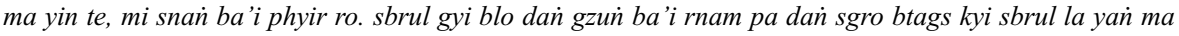
yin te, de dag ni rañ gi rañ bźin du yod pa la mi 'khrul pa'i phyir ro. 'on kyan் sgro btags kyi sbrul gañ źig phyi rol gyi sbrul ñid du nes par byas pa de ni sgrub pa dan் dgag par nes pa bźin no.

34 This translation is taken from Mc Allister (2011, p. 90), where I have also looked at the preceding objection. For a German translation, see Frauwallner (1937, p. 265 f.). 
Dharmottara is explaining in which way an affirmation and negation, such as "It is," and "It is not,", can be applied to an object of conceptual cognition. In his opinion, that object has to be something of which both existence and non-existence can be predicated, because conceptual cognitions obviously are able to judge both present and absent objects. ${ }^{35}$

Dharmottara is illustrating what he thinks this object to be. He lists a few things which this object is not, and then he defines it. He uses the example in which someone takes a piece of rope to be a snake. The elements involved in this confusion are as follows:

1. a rope,

2. the awareness of "snake",

3. the grasped form "snake",

4. the snake which is superimposed,

5. the superimposed snake that is ascertained as an external snake.

According to Dharmottara, the rope does not actually appear in the conceptual cognition "This is a snake," and hence there can be no affirmation or negation directed at it.

Elements 2-4, however, are manifest in the judgement "This is a snake." It is for this reason, so Dharmottara holds, that they can actually not be the object of affirmation or negation. As elements manifest in such a cognition, they exist undoubtedly. This means that it would be contradictory to negate any of those elements, because they directly appear to awareness with their own nature, and it would be redundant to affirm them for the same reason.

The only element that remains is the superimposed snake that is ascertained as an external snake (sgro btags kyi sbrul gan źig phyi rol gyi sbrul ñid du nes par byas $p a$ ). In its general form, this element is called "a superimposed [object] ascertained as being external" (sgro btags gañ źig phyi rol ñid du nes par byas pa de). It is this "superimposed thing that is ascertained as external" which alone can be affirmed or negated, according to Dharmottara. Since Dharmottara argues that elements 2-4 are not the object of conceptual cognition because they are directly manifest in selfawareness, it can be assumed that the superimposed thing ascertained as external is not manifest in self-awareness-implying that it is not grasped at all.

This marks a first difference to Ratnakīrti's understanding of what can be, at least conventionally, affirmed or negated: according to him, it is an external object. According to Dharmottara, it is the superimposed thing, qualified by being ascertained as external, that affirmation and negation can be directed at. ${ }^{36}$

A next point of interest is to see why they arrive at these different judgements. Ratnakīrti, in the discussion following his statement about Dharmottara's wrong opinion, points out a criticism that could be advanced against imposition:

\footnotetext{
35 This is also the context in which the verse from Passage 1 appears in Jñānaśrīmitra's AP.

36 Notice that Dharmottara does not make use of the tattvatas-samvṛtyā distinction as Ratnakīrti did. As mentioned above in footnote 9, Jñānaśrīmitra criticizes Dharmottara exactly for this point. But Ratnakīrti is silent on this issue.
} 
Passage 7: Criticism of imposition due to similarity Therefore, ${ }^{37}$ the state of determining this [object] is, because of a relation to a specific form, the state of being generative of the activity towards this [object]. But we do not speak of activity due to a superimposition because of similarity, so that there would be the possibility of a falsification [of our position] by means of superimposition [either] of an external object on a form of awareness or of a form of awareness on an external object; rather[, we say], an awareness-arising only in virtue of the ripening of one's own remaining impressions-even though not seeing an external object, brings forth activity towards an external object. Thus, [conceptual cognition] is completely mistaken.

Ratnakīrti here equates two things, the state of determining an object and the state of producing activity towards that object, and then continues to say that activity due to either of two kinds of superimposition is not accepted. ${ }^{38}$

This is the cue to take a closer look at what Dharmottara takes determination to be, ${ }^{39}$ and brings us to the following passage from the DhAP:

\footnotetext{
37 AS 66.2-5: tasmāt tadadhyavasāyitvam ākāraviśeșayogāt tatpravrttijanakatvam. na ca sādṛ́syād

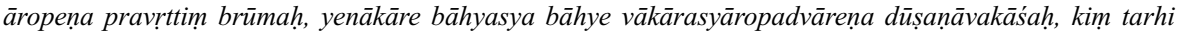
svavāsanāvipākavaśād upajāyamānaiva buddhir apaśyanty api bāhyam bāhye pravrịttim ätanotīiti viplutaiva.

${ }^{38}$ McCrea and Patil (2010, p. 169, n. 213) note about the parallel passage in AP 226.9-12 that "[t]his seems to be the position of Dharmottara, who argues that the conceptually constructed 'determined particular' is superimposed on the real external particular." Note that in the AP, the explicit criticism of Dharmottara appears only 3 pages (AP 229.16-17) after this statement (AP 226.9-12). But in Ratnakītti's rearrangement of arguments, this way of taking the argument would certainly be the most natural understanding. The only reservation I have in equating this position to Dharmottara's is that I have not yet been able to find a clear passage in which Dharmottara says that superimposition is due to similarity.

${ }^{39}$ To ask what he takes superimposition to be would be the same question, at least from the perspective of Ratnakīti, CAPV 135.31-136.2:
}

\begin{abstract}
tathā vikalpāropābhimānagrahaniścayādayo 'py adhyavasāyavat svākāraparyavasitā eva sphuranto bāhyasya vārtāmātram api na jānantīty adhyavasāyasvabhāvā eva śabdapravrttinimittabhede 'pi, tat katham yuktyāgamābahirbhūto 'nātmāsphuranam ācakșìta. (Read śabdapravrttinimittabhede 'pi acc. to RNĀms 73a1 against the misprinted śabdapravrttimittabhede 'pi CAPV 136.1. Thakur's emendation of yuktyāgamābahir to yuktyāgamabahir seems unnecessary. Translation: In the same way, also conceptual cognition, imposition, conceit, taking [something as something], restrictive fixation and so on, like determination, only ending in [cognition's] own form, [in as far as they] appear, know not even the merest news of an external [thing]. So [these] have only the nature of determination, even though there are different causes for the use of [these] words. Thus, how should someone not transgressing reasoning and scripture assert a manifestation of what is not [cognition's] self?)
\end{abstract}

For Ratnakīti's defense against the objection that this equation is against what is commonly accepted, what the authoritative teachers taught and what is reasonable, cf. CAPV $136.3 \mathrm{ff}$. What makes the difference for Ratnakīrti is the qualifier of all these conceptual operations, svākāraparyavasitā eva. According to my understanding, none of these operations has any kind of phenomenal access to (or manifestation of) an external thing. Determination is only a directing of activity at something external, not a representation thereof. 
Passage 8: Dharmottara on determination [Opponent]: Now, ${ }^{40}$ is it not so that conceptual cognition determines its own appearance, which is without the object, as the object? Therefore, this [appearance] is its object. [Dharmottara:] What is this [thing] called determination? Is it a grasping, or rather a making, or a joining, or a superimposing? Amongst these [alternatives], how could conceptual cognition grasp its own appearance, which is without the object, as the object, or make [it so]? For one [thing] can not be made to have the nature of another. Also, how could [conceptual cognition] join [its] self with a particular, which is not grasped [by conceptual cognition]? If, furthermore, superimposition is preceded by perception, conceptual cognition does not, after first perceiving [this cognition's] own appearance, superimpose [that appearance] later; [for,] if a thing which lasts for two moments does not exist, then how would this [conceptual cognition] superimpose onto another object at a later time [its] self that was perceived earlier? Or, if it is at the same time that [it] perceives its own nature and superimposes it as an object, well then, if so, then that which is superimposed at the same time as the appearance [of cognition] is perceived is not the nature of appearance. Therefore, it is established that an object which does not exist is the object of conceptual cognition. This also is assumed [by us]. [Opponent:] Now, it was said: "[Conceptual cognition] is active through determining [its] own appearance, which is without the object, as the object." 41 What does that mean? [Dharmottara:] The meaning is this: the grasped form is not cognized as different from the superimposed nature.

Very much the same passage is attributed to Trilocana by Ratnakīti, and reproduced by Vācaspati in his Nyāyavārttikatātparyațīka (NVTṬ), where it is said to conform to the intention of Dharmottara. ${ }^{42}$

\footnotetext{
${ }^{40}$ DhAP 238.7-25: gal te rnam par rtog pa ran் gi snan ba don med pa la don du lhag par źen pa ma yin nam, de'i phyir de ni de'i yul yin no źe na, ci ste lhag par źen pa źes bya ba 'di ci yin, ci 'dzin pa yin nam, 'on te byed pa yin nam, de ste sbyor ba yin nam, ci ste sgro 'dogs pa yin, de la rnam par rtog pa ran gi snan் ba don med pa la don du 'dzin par ji ltar 'gyur, byed par yan் ji ltar 'gyur te, gźan ni gźan gyi ran bźin du bya bar nus pa ma yin no. ma bzun ba'i ran் gi mtshan ñid dan bdag ñid sbyor bar yan் ji ltar 'gyur, sgro 'dogs pa yan் ñams su myon் ba sn்on du 'gro ba can yin na, rnam par rtog pa ni síar ran் gi snan் ba myon் nas phyis sgro 'dogs pa yan் ma yin te, dinos po skad cig gñis su sdod pa ni med na de ji ltar sñar ñams su myon ba'i bdag ñid phyis don gźan la sgro 'dogs par byed, ci ste ran் gi ran் bźin ñams su myon் ba dan், don du sgro 'dogs pa dan் dus mñam pa yin na de ltar na ni 'o na snan் ba ñams su myon்s ba dan் dus mñam du sgro btags pa snan் ba'i ran் bźin ma yin pas di்os po med pa rnam par rtog pa'i yul yin no źes gnas pa de yan் 'dod pa yin no. 'o na rañ gi snan் ba don med pa la don du źen nas 'jug pa yin no źes bśad pa 'di'i don gañ yin źe na, sgro btags pa'i ran bźin de las gzun ba'i rnam pa bye brag tu ma rtogs pa źes bya ba'i don 'di yin no. For a German translation, see Frauwallner (1937, 258 f.). Kataoka (2009, p. 483, fn. 18) comments on the last part of this passage, saying that it marks a reinterpretation of, and hence difference to, Dharmakirti's statement concerning activity through determination, and that this way of taking it is also confirmed by Jayanta's view on the matter.

41 Cf. PVin 246.7.

42 I am aware of only three notes about this passage in secondary literature: the most recent one is in Moriyama (2011), but since I do not know Japanese I cannot say much about it. The oldest note, by Frauwallner (1937, p. 258, n. 1), simply points out that the passage is similar to the one found in NVTT. The only detailed note is by Oberhammer (1964, p. 141, fn. 26), who has used this passage in explaining the development of the Naiyāyika's svābhāvikasambandha. He says about this passage that it is directed against Dharmottara's theory of conceptual cognition ("Vorstellung"), and is a polemical adaptation
} 
So Dharmottara is claiming that activity results from a failure to understand the difference between the grasped form and the superimposed nature. This superimposed nature (sgro btags pa'i ran bźin) I take to be the "superimposed [thing] ascertained as external" (sgro btags gan źig phyi rol ñid du nes par byas pa) from above. $^{43}$

This of course is different to Ratnakīrti's classification of conceptual cognition as àtmakhyāti, and should be regarded as asatkhyāti, on the basis that conceptual cognition's object is nistattva (cf. note 30). ${ }^{44}$ In addition, we can see from the above explanation that the main error of conceptual cognition lies in not grasping a difference between the external thing and the form grasped by cognition. ${ }^{45}$

This position is explicitly rejected by Ratnakīrti:

Passage 9: Determination as not grasping a difference $\mathrm{And}^{46}$ neither is the nongrasping of a difference [between cognition's own form and an external thing] to be called determination. ${ }^{47}$ For [it is] so: [is the difference not grasped] in [the case of] a grasped external [thing] or in [the case of an] ungrasped [external thing]? Not the first position, because the grasping of an external [thing] was rejected. Or because, if there is a grasping [of an external thing], [there is] the

\section{Footnote 42 continued}

("polemische Bearbeitung-zum Teil im gleichen Wortlaut") of the corresponding passage in the DhAP. But he does not point out what it is exactly that is polemical in this passage, and I must admit that I fail to see the point. Having given my own translation attempt above, and having closely studied Frauwallner's translation (Frauwallner 1937, p. 258 f.), I think there is no difference to Dharmottara's position that the object that one acts towards is an unreal, superimposed thing. So the consequences drawn by Trilocana (as reported by Ratnakīrti) and Dharmottara are, in my opinion, the same.

43 DhAP 239.11-13: gan gi phyir sgro btags pa la ni phyi rol du nes par byas pa yin pa'i phyir phyi rol 'dra ba phyi rol gyi gzugs brñan źes brjod par nus pa yin no. (Because regarding the superimposed [thing] one can say "reflection of an external [thing]" like "external thing," since [the superimposed thing] is ascertained as external.) Frauwallner (1937, p. 260) understands: "Denn beim Übertragen kann man, weil es als außen bestimmt wird, wie beim Äußeren von einem Spiegelbild des Äußeren sprechen.”

44 Support for this estimate of Dharmottara's position is found in Jayanta. Cf. the explanations given in Kataoka $\left(2009,483 \mathrm{f}\right.$ ), and see Jayanta's text in $\mathrm{NM}_{\mathrm{K} 2} 463 \mathrm{ff}$. According to Jayanta, Dharmottara is to be counted as following the path of asatkhyāti, whereas Dharmakīrti follows that of àtmakhyāti.

45 Cf. also DhAP 251.3-12, translated by Akamatsu (1986, 74 f.), where Dharmottara states that, upon having cognized an absolute negation as superimposed on conceptual cognition, one determines an external absolute negation "...en vertu de la détermination de la non-différence (abhedādhyavasāya) [entre ces deux négations absolues].” (Akamatsu 1986, p. 75)

46 CAPV 135.1-4: na ca bhedāgraho 'dhyavasāyo vaktavyaḥ. tathā hi kim bāhye grnyamāne 'grahyamāne vā. na ca prathamah pakșah, bāhyagrahanasya pratikșiptatvāt, grahane vādhyavasāyasya pratyakșatāprasañgāt. agṛhyamāṇe tu bāhye pravṛttiniyamo na syāt, anyeșām api tadānīm agrahaṇād anyatrāpi pravrttiprasañgāt.

47 This is the last of a list of candidates for determination that Ratnakīrti discusses and refutes (CAPV 133.24-135.31). His conclusion, after backing his arguments against these possibilities with quotes from Trilocana and Vācaspati, is that determination just breaks apart in whichever way it is considered: CAPV 135.30-31 tasmād yathā yathāyam adhyavasāyaś cintyate, tathā tathā viśziryata eva. (Cf. the conclusion at SāSiŚā 389.8: tasmād yāvac cintyate, tāvad āropyasparśābhāvan nāropo nāma.) The options listed by Ratnakīti in CAPV 133.25-28 fall into two groups: the first group contains candidates for determination that have only one element, brought to awareness by appearance, and the second has two elements, internal and external, brought together by some form of cognitive function. Interestingly, the second group also contains ekikaranam, identifying the external thing and the internal appearance, which, according to Kataoka (2009, p. 481), is how Jayanta sees Dharmakīrti's position. 
[unwanted] consequence of determination being perception. But if an external [thing] is not being grasped, there would not be a restriction of activity, because of the consequence that [there is], due to the non-grasping of others as well at that time, activity towards [these] others as well.

Ratnakīrti is here pointing out the various difficulties of the position that determination is the non-grasping of a difference between a form internal to cognition and something external to cognition. This can be seen as a broad attack on positions such as Dharmottara's. The option best suited to Dharmottara's opinion is the second: a nongrasping of that difference without grasping an external thing. That this external component is not grasped on Dharmottara's theory is evident: the material entity (the rope in Passage 6) is not grasped by conceptual cognition, and the superimposed thing ascertained as external, the object of activity according to Dharmottara, is not grasped, since that is what differentiates it from the other elements of conceptual cognition, and makes it that cognition's only viable object in the first place. Ratnakīrti concludes that successful activity cannot be explained in this theory, because it would be directed at all external things, since they are also not grasped: for how should an ungrasped difference between a form of cognition and an ungrasped thing allow a person to act towards one specific thing, rather than towards another?

\section{Conclusion}

So what is the answer to the leading question: what is it that Ratnakīrti criticizes about Dharmottara's theory of conceptual cognition?

The main points are these:

1. There is a disagreement about the object of activity. For Ratnakirti, it is an object external to cognition which one acts towards in a conventional manner. For Dharmottara, the object is a superimposed thing that is deemed external, which is to say, the externality of the superimposed thing.

2. This difference about activity's object can be traced to two causes:

(a) A difference about how determination is understood. For Dharmottara, determination consists in not grasping the difference between the (externally) superimposed nature and the grasped form of awareness itself, whereas for Ratnakīrti determination is simply the fact that conceptual awareness can direct activity at an external thing; there is no actually external element involved in this determination.

(b) A difference about the ontological status of the object of activity. For Dharmottara, it is superimposed and unreal (nistattva, alikka); for Ratnakīrti it is a generalized external object (which is conventionally taken to exist).

We see that the two issues under the second point are about what appears to a conceptual cognition, and about how it appears to it. In other words, this is a discussion about the status of the form, or $\bar{a} k \bar{a} r a$, appearing in a conceptual cognition, and about the epistemological framework in which this form is 
embedded. It is interesting to note that the main criticism that Ratnakīti advances against Dharmottara's apoha theory is actually a broad attack on Dharmottara's epistemology, at least on the part that is concerned with conceptual cognition. Cognitive forms, and the epistemological functions concerned with them, are thus at the centre of their debate. From this we can conclude that their differences about apoha are not so much due to their ideas of exclusion, as rather to the fact that their epistemological points of view differ. That means that the differences in their apoha theories should, in my opinion, be explained as the result of more fundamental disagreements in their epistemological positions, and not as a cause for these disagreements. Another indication for the existence of this underlying issue is that it influences various theories. It is for this reason that it appears in different contexts of Ratnakirti's work: in the AS and in the CAPV.

If it is correct that Dharmottara and Ratnakīti's disagreement is essentially due to their different views of how determination works and what the form of cognition is, then it could be worthwhile to study whether this difference is also at the heart of other discussions about conceptual cognition in that period of Indian philosophy. A starting point could be the following question: What is the relation of Dharmottara and Trilocana (as well as Vācaspatimiśra) concerning determination, that is, the cognitive function burdened with making a form appearing in cognition into an actionable object?

Open Access This article is distributed under the terms of the Creative Commons Attribution License which permits any use, distribution, and reproduction in any medium, provided the original author(s) and the source are credited.

\section{Abbreviations}

AP Jñānaśrīmitra. Apohaprakaraṇa. In JNĀ (pp. 201-232).

AS Ratnakīrti. Apohasiddhi. In RNA $\bar{A}^{2}$ (pp. 58-66).

CAPV Ratnakīrti. Citrādvaitaprakāśavāda. In RNĀ² (pp. 129-144).

DhAP Dharmottara. Apohaprakaraṇa. In Frauwallner 1937 (pp. 235-254).

JNĀĀ Ahakur (Ed.) (1987). Jñānaśrīmitranibandhāvali. Buddhist Philosophical Works of Jñānaśrīmitra.

Patna: Kashi Prasad Jayaswal Research Institute.

NBṬ Dharmottara. Nyāyabinduțīkā. In Malvania 1971.

NK Vācaspatimiśra. Nyāyakaṇikā. In Goswami 1984.

$\mathbf{N M}_{\mathbf{K} 2}$ B. Jayanta. Nyāyamañjarī. Bauddhair Apohadūṣaṇoddharaṇa. In Kataoka 2009 (pp. 473-458).

NMGBh Cakradhara. Nyāyamañjarīgranthibhañga. In Shah 1972.

NVTṬ Vācaspatimiśra. Nyāyavārttikatātparyațīkā. In Thakur 1996.

PVin2 Dharmakīti. Pramānaviniścaya 2. In Steinkellner 2007 (pp. 45-101).

RNĀ ${ }^{1}$ A. Thakur (Ed.) (1957a). Ratnakīrtinibandhāvalī. Buddhist Nyāya Works of Ratnakīrti. Patna: Kashi Prasad Jayaswal Research Institute.

RNA $\bar{A}^{2}$ A. Thakur (Ed.) (1975b). Ratnakīrti-nibandhāvalih. Buddhist Nyāya Works of Ratnakīrti. Patna: Kashi Prasad Jayaswal Research Institute.

RNĀms Ratnakīrti. Ratnakīrtinibandhāvali. A manuscript photographed by Sānkrụtyāyana. The negatives are kept in Patna (cf. Much 1988). I had available to me scans based on copies of those negatives, kept in the "Sammlung des Seminars für Indologie und Buddhismuskunde in Göttingen." Cf. the description of item "Xc 14/26" in Bandurski (1994: 58-60), as well as Thakur (1975a). This ms is the basis for the two editions RNĀ1 and RNĀ2 . Jñānaśrīmitra. Sākārasiddhiśāstra.

SāSiŚā In JNĀ (pp. 367-513).

VP Aniruddha. Nyāyabhāṣyavārttikatātparyavivaraṇapanjikā. In Thakur 1969. 


\section{References}

Akamatsu, A. (1986). Vidhivādin et Pratiședhavādin. Double aspect présenté par la théorie sémantique du bouddhisme indien. Zinbun: Memoirs of the Research Institute for Humanistic Studies, 21, 67-89.

Bandurski, F. (1994). Übersicht über die Göttinger Sammlungen der von Rāhula Sānkrtyāyana in Tibet aufgefundenen buddhistischen Sanskrit-Texte (Funde buddhistischer Sanskrit-Handschriften, III). In F. Bandurski, B. Pāsādika, M. Schmidt, \& B. Wang (Eds.), Untersuchungen zur buddhistischen Literatur (pp. 9-126). Göttingen: Vandenhoeck \& Ruprecht.

Chu, J. (2004). A study of Sataimira in Dignāga's definition of pseudo-perception (PS 1.7cd-8ab). Wiener Zeitschrift für die Kunde Südasiens, 48, 113-149.

Frauwallner, E. (1937). Beiträge zur Apohalehre: II: Dharmottara. Wiener Zeitschrift für die Kunde des Morgenlandes, 44, 233-287.

Goswami, M. L. (Ed.). (1984). Vidhiviveka of Śrī Maṇdana Miśra with the commentary Nyāyakaṇikā of Vācaspati Miśra. Varanasi: Tara Printing Works.

Hattori, M. (2006). The Apoha theory as referred to in the Nyāyamañjarī. Acta Asiatica: Bulletin of the Institute for Eastern Culture,90, 55-70.

Kajiyama, Y. (1998). In E. Steinkellner (Ed.), An introduction to Buddhist philosophy. An annotated translation of the Tarkabhāṣā of Mokșākaragupta. Vienna: Arbeitskreis für Tibetische und Buddhistische Studien Universität Wien.

Kataoka, K. (2009). A critical edition of Bhața Jayanta's Nyāyamañjarī: The Buddhist refutation of Kumārila's criticism of apoha. The Memoirs of the Institute of Oriental Culture, University of Tokyo, 156(December), 498-458.

Katsura, S. (1986). Jñānaśrīmitra on apoha. In B. K. Matilal \& R. D. Evans (Eds.), Buddhist logic and epistemology. Studies in the Buddhist analysis of inference and language (pp. 171-183). Dordrecht: Reidel.

Malvania, P. D. (Ed.). (1971). Paṇita Durveka Mīśra’s Dharmottarapradīpa (Being a sub-commentary on Dharmottara's Nyāyabinduțīā, a commentary on Dharmakīrti's Nyāyabindu). Patna: Kashi Prasad Jayaswal Research Institute.

Mc Allister, P. (2011). Ratnakīrti's Apohasiddhi. A critical edition, annotated translation, and study. $\mathrm{PhD}$ dissertation, Institute for South Asian, Tibetan, \& Buddhist Studies, University of Vienna. http://othes.univie.ac.at/17119/.

Mc Allister, P. (Forthcoming). Determination (adhyavasāya) in Ratnakīrti's Apohasiddhi. In P. Mc Allister, C. A. Scherrer-Schaub, \& H. Krasser (Eds.), Cultural flows across the Western Himalaya.

McCrea, L. J., \& Patil, P. G. (2006). Traditionalism and innovation. Philosophy, exegesis, and intellectual history in Jñānaśrīmitra's Apohaprakaraṇa. Journal of Indian Philosophy,34(4), 303-366.

McCrea, L. J., \& Patil, P. G. (2010). Buddhist philosophy of language in India. Jñannaśrīmitra on exclusion. New York: Columbia University Press.

Moriyama, S. (2011). An annotated Japanese translation of Ratnakīrti’s Citrādvaitaprakāśavāda (1). South Asian Classical Studies, 6, 51-92.

Much, M. T. (1988). A visit to Rāhula Sänikrtyāyana's collection of negatives at the Bihar Research Society: Texts from the Buddhist epistemological school. Wien: Arbeitskreis für Tibetische und Buddhistische Studien Universität Wien.

Oberhammer, G. (1964). Der Svābhāvika-Sambandha, ein geschichtlicher Beitrag zur Nyāya-Logik. Wiener Zeitschrift für die Kunde Süd- und Ostasiens und Archiv für indische Philosophie,8, 131-181.

Patil, P. G. (2003). On what it is that Buddhists think about. apoha in the Ratnakīrti-Nibandhāvali. Journal of Indian Philosophy,31(1-3), 229-256.

Patil, P. G. (2009). Against a Hindu God. Buddhist philosophy of religion in India. New York: Columbia University Press.

Patil, P. G. (2011, June). Without brackets. A minimally annotated translation of Ratnakīrti's demonstration of exclusion. Accessed 3 December 2012, from http://cup.columbia.edu/media/ 7285/side15360_patil.pdf.

Schmithausen, L. (1965). Maṇdanamiśra's Vibhramavivekah. Mit einer Studie zur Entwicklung der indischen Irrtumslehre. Vienna: Verlag der Österreichischen Akademie der Wissenschaften.

Shah, N. J. (Ed.). (1972). Cakradhara's Nyāyamañjarīgranthibhaìga (Vol. 35). Ahmedabad: L. D. Institute of Indology.

Steinkellner, E. (1976). Der Einleitungsvers von Dharmottaras Apo- haprakaraṇam. Wiener Zeitschrift für die Kunde Südasiens und Archiv für indische Philosophie,20, 123-124. 
Steinkellner, E. (1979). Dharmakīrtiśs Pramāṇaviniścayah. Zweites Kapitel: Svārthānumānam. Vol. 2: Übersetzung und Anmerkungen. Vienna: Verlag der Österreichischen Akademie der Wissenschaften.

Steinkellner, E. (Ed.). (2007). Dharmakīti’s Pramānaviniścaya. Chapters 1 and 2. Beijing: China Tibetology Research Center, Austrian Academy of Sciences.

Steinkellner, E., \& Much, M. T. (1995). Texte der erkenntnistheoretischen Schule des Buddhismus. Systematische Übersicht über die buddhistische Sanskrit-Literatur II/Systematic Survey of Buddhist Sanskrit Literature II. Göttingen: Vandenhoeck \& Ruprecht.

Thakur, A. (Ed.). (1969). Nyāyabhāṣyavārttikațīkāvivaraṇapanjikā [II-V] of Aniruddhācārya. Darbhanga: Mithila Institute of Post-Graduate Studies \& Research in Sanskrit Learning.

Thakur, A. (1975a). English introduction. In A. Thakur (Ed.), Ratnakīrti-niban-dhāvalih. Buddhist Nyāya works of Ratnakirti (pp. 1-25). Patna: Kashi Prasad Jayaswal Research Institute.

Thakur, A. (Ed.). (1975b). Ratnakīrti-nibandhāvaliḥ. Buddhist Nyāya works of Ratnakīrti. Patna: Kashi Prasad Jayaswal Research Institute.

Thakur, A. (Ed.). (1996). Nyāyavārttikatātparyațīkā of Vācaspatimiśra. New Delhi: Indian Council of Philosophical Research. 